\title{
INTELLIGENS HULLADÉGYÜJTÉSI RENDSZER INTEGRÁLÁSA CITY LOGISZTIKAI FOLYAMATOKBA
}

\author{
Bányai Tamás \\ egyetemi docens, Miskolci Egyetem, Logisztikai Intézet \\ 3515, Miskolc, Miskolci-Egyetemváros, email: altamas@uni-miskolc.hu \\ Mohammad Zaher Akkad \\ doktorandusz, Miskolci Egyetem, Logisztikai Intézet \\ 3515, Miskolc, Miskolci-Egyetemváros, email: zaherakkad91@gmail.com \\ Somody Dóra \\ BSc hallgató, Miskolci Egyetem, Logisztikai Intézet \\ 3515, Miskolc, Miskolci-Egyetemváros, email: somodydora@gmail.com
}

\begin{abstract}
Absztrakt
A negyedik ipari forradalom és az úgynevezett Ipar 4.0 technológiák fókuszában ugyan az egyedi vásárlói igények tömeggyártás hatékonyságával történö kielégitése áll az ellátási láncban szereplö eröforrások intelligens hálózatba kapcsolása révén, azonban hatékonyságnövelési törekvések nem csupán a termelés területén jellemzöek, hanem a szolgáltatási tevékenységekben is. Az Ipar 4.0 technológiák alkalmazása az ellátási láncok minden területén hatékonyságnöveléshez vezethet, ide értve a beszerzési, termelési, elosztási és inverz logisztikai folyamatokat. A hatékonyságnövelés és a mobilitás szoros kapcsolata nem csupán az ellátási láncokat, a first-mile és last-mile folyamatokat érinti, hanem a városi logisztika szempontjából is egyre inkább meghatározóvá válik. Jelen cikk keretében a szerzők a city logisztika kiber-fizikai rendszerként történö megvalósitására mutatnak példát elektromos jármüvek és mikromobilitási eszközök alkalmazásával. A bemutatott megoldás egy olyan intelligens rendszer, melyben olyan fel- és leadási feladatok optimális kiszolgálása végezhetö el nagy hatékonysággal, alacsony környezetterheléssel, mint postai csomagok kézbesitése, boltok ellátása áruval, vagy a kommunális hulladék gyüjtése.
\end{abstract}

Kulcsszavak: városi logisztika, mikromobilitás, közlekedés, hatékonyság, költségelemzés, megtérülés

\begin{abstract}
Within the frame of the fourth industrial revolution, Industry 4.0 technologies make it possible to fulfil diversified customers' demands with the efficiency of mass production through the integration of resources in the value making chain. This trend influences the behaviour of both production and service companies. The application of Industry 4.0 technologies has a great impact on the performance of all subprocesses of value making chains, like procurement, production, distribution and inverse logistics. The improvement of efficiency has a great impact on supply chain solutions, first-mile and last-mile processes and city logistics. Within the frame of this article the authors introduce a possible solution of city logistics as a cyber-physical system based on e-vehicles and micromobility. The described cyberphysical system makes it possible to fulfil customers' demands including waste collection or distribution of goods.
\end{abstract}

Keywords: city logistics, micromobility, transportation, efficiency, cost analysis, return of investment 


\section{Bevezetés}

A megnövekedett népesség nagy hatással van a keletkezö háztartási hulladékok mennyiségére. A hagyományos hulladékgazdálkodási rendszerek két fő részre oszthatók. Az első részt az újrafeldolgozási technológiák képviselik, ideértve az elégetést, a feldolgozást, az újrafelhasználást és az aprítást. A második rész a feldolgozással kapcsolatos logisztikai és anyagmozgatási műveleteket tartalmazza. A háztartási hulladék gyüjtését széles földrajzi területen végzik, ami azt jelenti, hogy az összegyüjtés az összes költség jelentős részét teszi ki. A hulladékkezelő rendszereknek naprakész technikai, technológiai és logisztikai megoldásokra van szükségük a hatékonyság, a megbízhatóság és a rugalmasság növelése érdekében. Az Ipar 4.0 technológiák alkalmazása jó lehetőséget kínál a hagyományos hulladékgyűjtő és -feldolgozó rendszerek kiber-fizikai rendszerbe történő átalakítására [1].

A szakirodalmi források a különféle hulladékgyüjtési megoldásokat részletesen elemzik, különös tekintettel a technológiai, logisztikai, a szabályozási, politikai és a szociális szempontokra [2]. A hulladékgyüjtő rendszer optimális felépítése befolyásolja a hulladékgyüjtési folyamatok teljesítményét. Egy portugál esettanulmány azt mutatja, hogy a hulladékgazdálkodási vállalatok stratégiai terjeszkedési tervei komplex matematikai modellekkel és heurisztikus optimalizálási algoritmusokkal támogathatók [3]. A többszintủ megoldások fontosságát emelik ki háromfázisú hierarchikus megközelítést alkalmazó, a spanyol Galícia régióban [4] és Ankarában [5] megvalósult esettanulmányok, amelyekben a szerzők telepítés és elrendezéstervezési, járattervezési és ütemezési feladatokat tárgyalnak.

A negyedik ipari forradalom legfontosabb jellemzője az intelligens technológiák alkalmazása, melynek révén elmoshatók a határok a fizikai, a digitális és a biológiai erőforrások között [6]. Az ipari fejlödés üteme folyamatosan növekszik. Az általunk megélt technológiai forradalom eredményei, az interneten felépített intelligens technológiák mellett, amelyek az Ipar 4.0-ból származnak, elengedhetetlenné teszik ezeknek a technikáknak a folytatását a CAD-modellezéstől [7] a digitális iker megoldásokig [8]. A hagyományos kommunális hulladékgyüjtési rendszerek hatékonysága jól fokozható Ipar 4.0 technológiák alkalmazása révén és megvalósítható a hagyományos folyamat kiber-fizikai rendszerré történő transzformációja. Ennek létjogosultságát az is igazolja, hogy 2019-ben az ipari termelés szektor 75\%-a alkalmazott Ipar 4.0 technológiákat folyamatainak fejlesztésére és a hagyományos rendszer - kiberfizikai rendszer transzformáció megvalósítására.

A mikromobilitás city logisztika területén történő alkalmazásának jelentőségét számos olyan szakcikk igazolja, mely többek között foglalkozik a mikromobilitás és a közösségi közlekedés integrációs lehetőségeinek vizsgálatával, a mikromobilitásban rejlő azon potenciális lehetőségek feltárásával, melyek révén csökkenthető a city logisztikai folyamatok környezetterhelése a különböző üvegház hatású gázok kibocsátásának csökkentése révén [9-12].

Jelen tanulmány keretében a szerzők ezen transzformáció lehetőségét mutatják be, különös tekintettel a logisztikai folyamatok hatékonyságának fokozására. Ennek érdekében a cikk a következő főbb tartalmi egységekből épül fel. A 2. fejezetben röviden bemutatásra kerülnek azok a föbb mikromobilitási eszközök, melyek egy city logisztikai rendszerben mikromegbízások teljesítése révén alkalmasak lehetnek a teljes rendszer hatékonyságának fokozására. Itt a mikromegbízásokat érdemes kiemelni, hiszen a mikromobilitási eszközök általában csak kis tömegü áruk szállítására alkalmasak (például roller vagy kerékpár esetében) és csak kivételes esetben lehet velük nagyobb tömegü árut szállítani (például mikroautó). A 3. fejezetben bemutatásra kerül egy lehetséges city logisztikai megoldás, melybe mind a mikromobilitás adta lehetőségek integrálva megjelennek, mind a kiber-fizikai hulladékgyüjtési rendszer koncepciója megvalósítható. A 4. fejezetben egy esettanulmányon keresztül kerül validálásra a bemutatott tervezési módszer. A következtetéseket és a jövőbeni kutatási irányokat az 5. fejezet tárgyalja. 


\section{A mikromobilitás, mint egy új eszköz a city logisztikai problémák megoldására}

A városi közlekedésben egyre inkább megjelennek az elektromos autók, illetve az elektromos mikromobilitási eszközök. A mikromobilitás eszközei esetében általános cél, hogy környezetkímélő és gazdaságos alternatívát kínáljanak az egyéni közlekedés hagyományos megoldásaival szemben, ugyanakkor egyre inkább felvetődik az a kérdés is, hogy ezen mikromobilitási eszközök hogyan alkalmazhatók áruszállítási mikrofeladatok megvalósítására. Mivel a mikromobilitás eszközei alapvetően a személyközlekedés last-mile részében jutnak jelentős szerephez, hiszen hatótávolságuk korlátozott, ezért jelen cikkben azt vizsgáljuk meg, hogy ezen eszközök hogyan illeszthetők be egy hatékony kiber-fizikai környezetben müködő city logisztikai folyamatba. A főbb mikromobilitási eszközök az elektromos kerékpárok, rollerek, hagyományos kerékpárok, gördeszkák, elektromos rollerek, hoverboardok, vagyis minden olyan (föként elektromos hajtású) eszköz, mely a városi közlekedésben az utolsó kilométerek megtételére alkalmas. Nézzünk meg néhány jellegzetes mikromobilitási megoldást:

- Elektromos segway (Segway Onewheel Ninebot S2): A segway az egyszerübb hoverboardokkal ellenétben egyenetlenebb talajon is jól mozgó egykerekủ eszköz, mely vízálló anyagból készül. Alapvetően felnőttek számára találták ki ezt az eszközt, de természetesen a gyerekek számára is szórakoztató elfoglaltság lehet ezzel közlekedni a városokban. Teljesítménye $500 \mathrm{~W}$, maximális sebessége $24 \mathrm{~km} / \mathrm{h}$, hatósugara $30 \mathrm{~km}$, töltési ideje 4 óra, a kerék átméröje 14”, az akkumulátor várható élettartama 6 hónap, tömege $11,4 \mathrm{~kg}$, hasznos terhe $120 \mathrm{~kg}$ (1. ábra).

- Elektromos Onewheel (Onewheel XR): Kyle Doerksen 2013-ban alkotta meg mikromobilitási eszközét, melynek célja hogy visszaadja a friss hó érzetét csakúgy, mint snowboardozás közben. Nagyrész használója helyett egyensúlyoz. Egész egyszerüen elöre dőlve megindul előrefele, hátra dőlve pedig hátrafele halad, vagy lassít. Hatótávolsága $25 \mathrm{~km}$, maximális sebessége $30 \mathrm{~km} / \mathrm{h}$, hajtását hypercore kefe nélküli motor biztosítja (1. ábra).
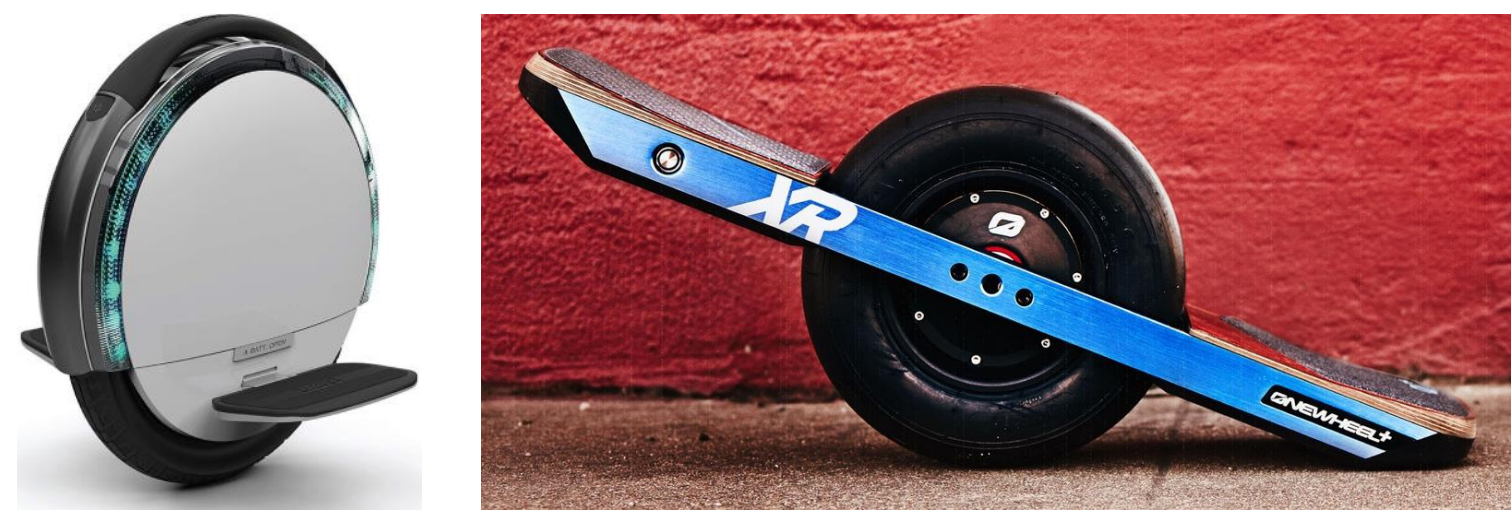

1. ábra. Segway Onewheel Ninebot S2 [13] és Onewheel XR [14].

- E-bike: Az elektromos kerékpárokon belül két típus különböztethető meg: a pedelec és az e-bike. Igazából mindkettő motorral felszerelt kerékpár, azonban van néhány fontos különbség. Az elektromos kerékpárok azok az e-bike-ok, melyek a pedál tekerése nélkül müködnek, az indításhoz szükséges a gázkar elfordítása. Németországban az e-bike-ok biztosítás, rendszám és jogosítvány kötelesek, hazánkban azonban a teljesítményhatár 250W [15]. Magyarországon is egyre jelentősebb szerepet töltenek be a mikromobilitási eszközök a városi közlekedésben, annak támogatottságára jó példa, 
hogy 2020 október 30-tól elérhető a vásárlást támogató elektromos rásegítésủ kerékpárokra vonatkozó, egymilliárd forint keretösszegü pályázat, melyet az Innovációs és Technológiai Minisztérium hirdetett meg. Mind pedálszenzoros, mind nyomatékszenzoros kerékpárokra lehet támogatásért pályázni. Mivel alapvető cél a munkába járás támogatása, ezért a pályázathoz munkaviszonyt igazoló dokumentum csatolása is szükséges.

- Elektromos roller: A 2000-es évek kezdetétől gyártott eszköz, mely 30 km hatótávolsággal rendelkezik, 500 wattos motor hajtja és becslések szerint $5000 \mathrm{~km}$ megtételére alkalmas teljes életciklusa alatt. Köszönhetően kis tömegének, a behajtható fogantyúknak és az intuitív lábbal hajtogatható mechanizmusának, egyszerủen lehet szállítani és akár tömegközlekedési jármủvekre felvinni. A lítium ion akkumulátorok töltési ideje 3,5 óra, maximális sebessége $30 \mathrm{~km} / \mathrm{h}$, hatótávolsága egy töltéssel $30 \mathrm{~km}$, tömege 13,5 kg. Az elektromos rollerek új generációját alkotta meg a Volkswagen a Cityskater és a Streetmate modellek formájában (2. ábra).
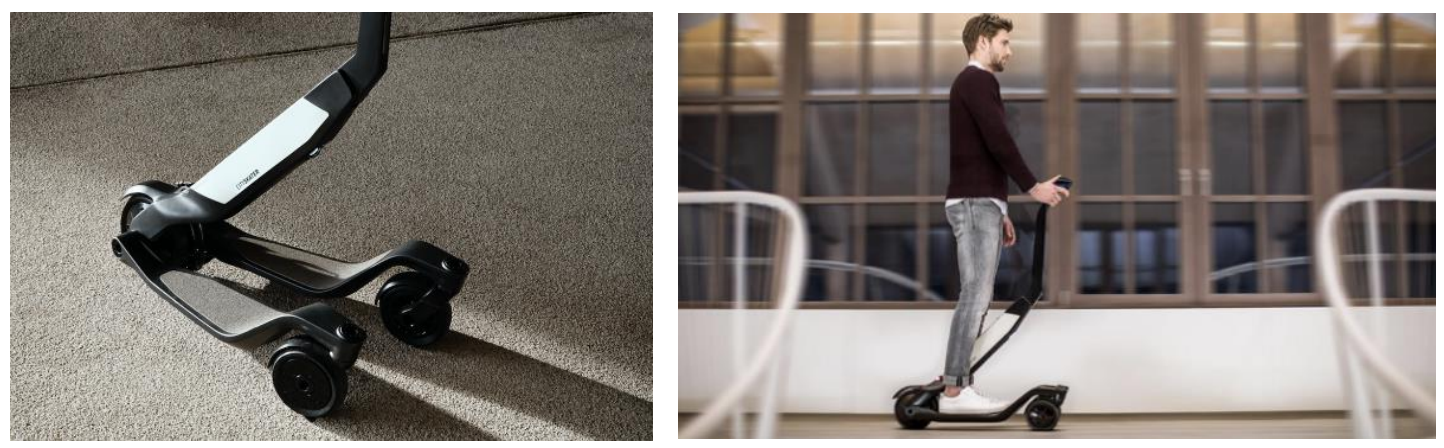

2. ábra. Cityskater és Streetmate [16].

- Elektromos robogó: A hagyományos robogók alternatívája, jogosítvány szükséges a használatához, mivel végsebessége $80 \mathrm{~km} / \mathrm{h}$ (3. ábra).

- Elektromos kisautó (Microlino): Méretéből kiindulva akár keresztirányban is parkolhat, ezért csak harmadannyi helyre van szüksége, mint egy normál autónak. Mivel ajtaja elöre nyílik ezért a parkoló autóból is egyszerüen megoldható a kiszállás. Kis mérete ellenére a Microlino rengeteg helyet foglal magába. Az ülésen két felnőtt számára van hely, csomagtartója 220 literes (3. ábra).
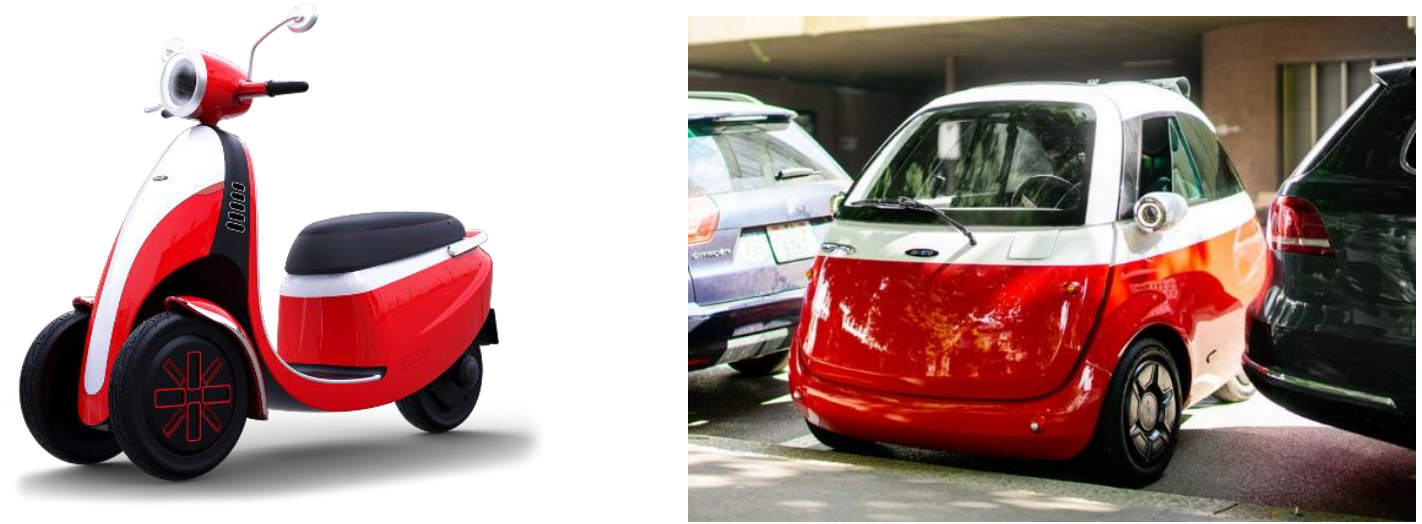

3. ábra. Elektromos robogó [17] és elektromos kisautó [18]. 


\section{Hulladékgyưjjtési folyamat integrálása intelligens city logisztikai környezetbe}

A hagyományos kommunális hulladékgyüjtési rendszerek müködése az Ipar 4.0 technológiák alkalmazásával nagy mértékben javítható, ezáltal növelhető az abban lévő erőforrások kihasználtsága, csökkenthető a rendszer környezetterhelése és fokozható a szolgáltatási színvonal. A szakirodalomban találhatók olyan források, melyek a hagyományos hulladékgyüjtési rendszerek kiber-fizikai környezetbe történő transzformációs lehetőségeit tárgyalják [2, 19]. Ugyanezen folyamatok kialakítása önmagában is hatékonyságnövekedés eredményez, azonban jelentősen nagyobb hatása lehet ezen hulladékgyüjtési folyamatot a városi logisztikai rendszerbe integrálva kezelni (4. ábra).
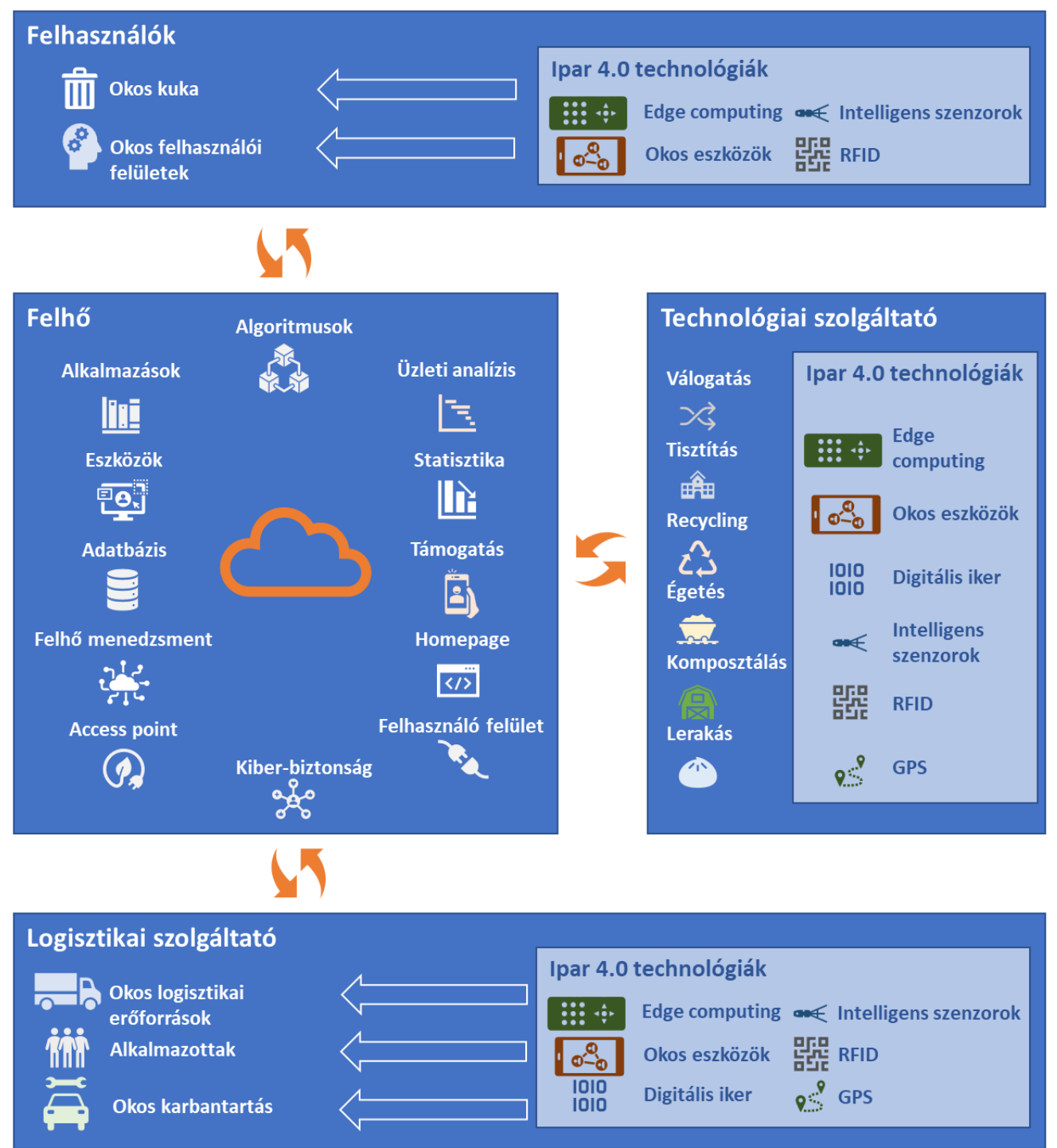

4. ábra. Hulladékgyüjtési folyamat integrált megjelenése city logisztikai rendszerben.

Jelen cikk keretében egy belvárosi környezetben működő többszintes city logisztikai megoldás Ipar 4.0 technológiákon alapuló megoldása kerül bemutatásra. A külső szolgáltatók a belvárosba irányuló árut 
egy logisztikai központban helyezik el, mely a belvárosi régió határán található. Ezen logisztikai központból elektromos járművek vagy mikromobilitási eszközök segítségével történik meg az áruk leadási pontokra történő eljuttatása. Gyüjtési folyamat esetén az ellátási lánc iránya változik. Az elektromos jármüvek összegyüjtik az érintett régióban lévő feladási igényeket és eljuttatják a logisztikai központba, ahonnan már a hagyományos szolgáltatók végzik az összegyüjtött áruk továbbszállítását. Ezen rendszer esetében - ellentétben egy hagyományos ellátási lánccal - a folyamatok optimalizálása centralizálható, ezáltal a rendelkezésre álló logisztikai erőforrások közötti kooperáció révén az energiafogyasztás és az emisszió csökkenthető.

Az intelligens ágens feladata az egyes ellátási feladatok ütemezése, feladatok és járatok összerendelése, a járatok tervezése és irányítása, mely során idő-, távolság-, energiafogyasztás- és emisszió-alapú célfüggvényeket vesz figyelembe kapacitásokra, időkre, alkalmasságra, rendelkezésreállásra, energiafogyasztásra és szolgáltatási színvonalra vonatkozó korlátozásokkal (5. ábra).

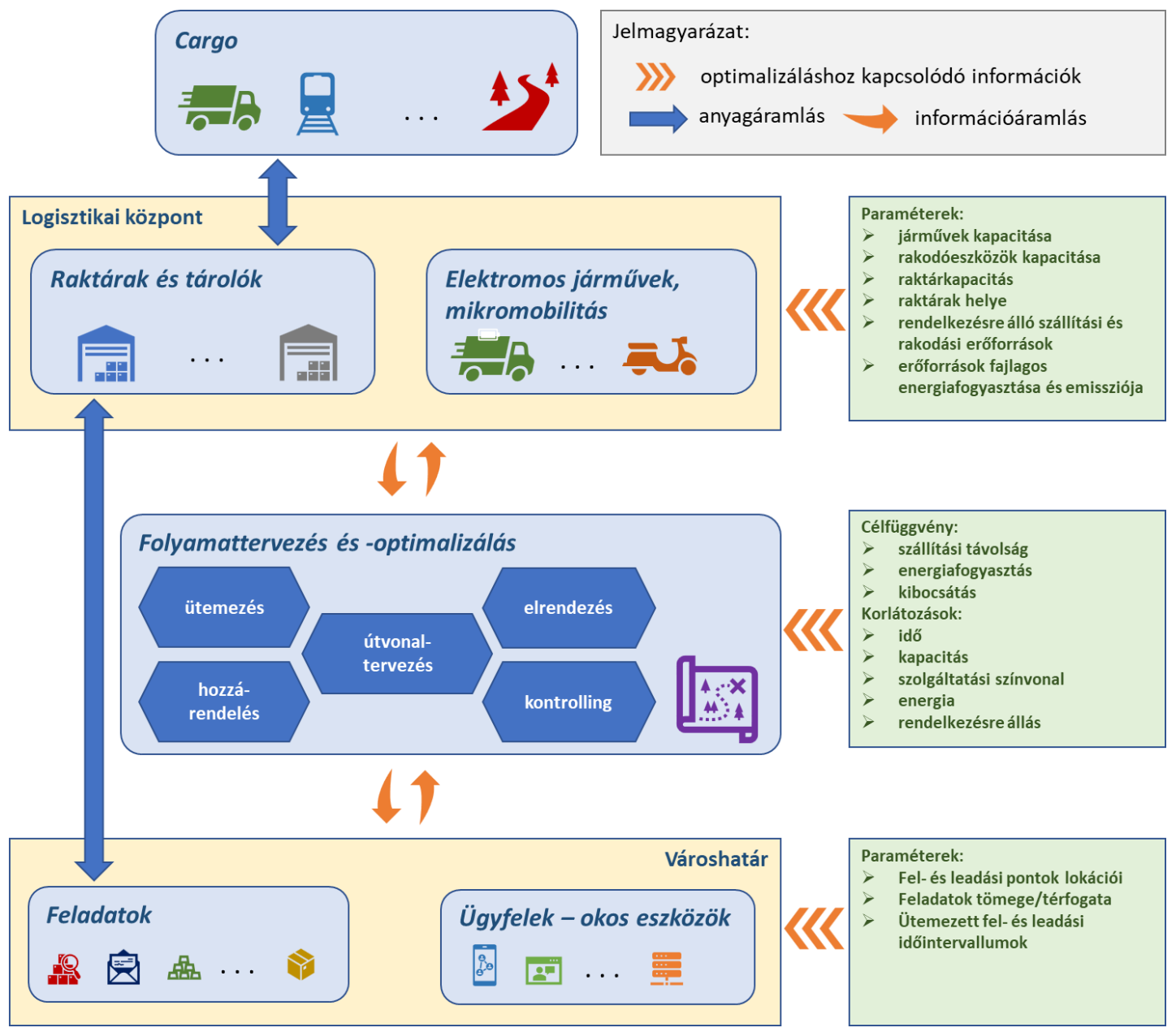

5. ábra. A valós folyamatok és a matematikai modell kapcsolata.

Jelen esettanulmány egy olyan elektromos jármüveken alapuló rendszert mutat be, melyben a teljes rendszer hatékony müködésének a kulcsát az olyan Ipar 4.0 technológiák alkalmazása jelentheti, mint 
az okos eszközök, intelligens szenzorok, digitális iker megoldások, szimuláció alapú folyamatfejlesztés, felhő- és ködalapú számítástechnika.

Az alábbi esettanulmányban a következö paramétereket tekintjük adottnak: a fel- és leadási pontok helye, a fel- és leadási feladatok tömege/térfogata, az egyes fel- és leadási feladatokhoz rendelhető időablakok. A logisztikai központ vonatkozásában az optimalizálás bemenő paramétere a logisztikai központ helye és tárolási kapacitása, a rendelkezésre álló logisztikai erőforrások (például rakodó berendezések) és azok kapacitásai, fajlagos emisszió, logisztikai erőforrások energiafogyasztása.

A tervezés során használt elsô célfüggvény a szállítási útvonalak hossza a vizsgálati időhorizonton belül elvégzett fel- és leadási feladatok esetében:

$$
L=\sum_{\alpha=1}^{\alpha_{\max }} \sum_{\beta=1}^{\beta_{\max }^{\alpha}-1} l\left(p_{y_{x_{\alpha, \beta}}}, p_{y_{x_{\alpha, \beta+1}}}\right) \rightarrow \min
$$

ahol $L$ a teljes szállítási útvonalak hossza a tervezési időhorizonton, $\alpha$ a járművek száma, $\beta_{\text {max }}^{\alpha}$ az $\alpha$. járathoz rendelt fel- és leadási pontok száma, $x_{\alpha, \beta}$ az $\alpha$. járathoz $\beta$. feladatként rendelt fel- vagy leadási feladat azonosítója, $y_{x_{\alpha, \beta}}$ fel- és leadási pont azonosítója, $p_{y_{x_{\alpha, \beta}}}$ az $\alpha$. járathoz $\beta$. feladatként rendelt felvagy leadási feladat pozíciója és $l$ a szállítási távolság az egyes fel- és leadási pontok pozíciójának függvényében.

A második célfüggvény az energiafelhasználás minimalizálása:

$$
C^{e F U E L}=\sum_{\alpha=1}^{\alpha_{\max }} \sum_{\substack{\beta=1 \\ \rightarrow \text { min. }}}^{\beta_{\max }^{\alpha}} l\left(p_{y_{\alpha, \beta},}, p_{y_{x_{\alpha, \beta+1}}}\right) \cdot q_{x_{\alpha, \beta}} \cdot c_{\alpha, \beta}^{e F T}\left(q_{x_{\alpha, \beta}}\right)+\sum_{\alpha=1}^{\alpha_{\max }} \sum_{\beta=1}^{\beta_{\max }^{\alpha}} c_{\alpha, \beta}^{e F M H}\left(q_{x_{\alpha, \beta}}\right)
$$

ahol $C^{e F U E L}$ az elektromos jármű vagy a mikromobilitási eszköz energiafogyasztása [kWh].

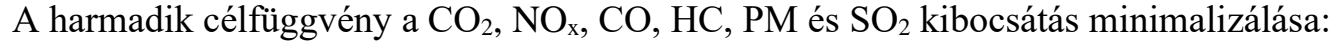

$$
E^{r}=\sum_{\alpha=1}^{\alpha_{\max }} \sum_{\beta=1}^{\beta_{\max }^{\alpha}-1} l\left(p_{y_{x_{\alpha, \beta}},} p_{y_{x_{\alpha, \beta+1}}}\right) \cdot c_{\alpha, \beta}^{e F T} \cdot e_{\alpha, \beta}^{r}+\sum_{\alpha=1}^{\alpha_{\max }} \sum_{\beta=1}^{\beta_{\max }^{\alpha}} c_{\alpha, \beta}^{e F M H}\left(q_{x_{\alpha, \beta}}\right) \cdot e_{\alpha, \beta}^{r} \rightarrow \text { min. }
$$

ahol $c_{\alpha, \beta}^{e F T}$ az elektromos jármü, illetve a mikromobilitási eszköz fajlagos energiafogyasztása [kWh/ERKEkm (ERKEkm = egységrakomány képző eszköz kilométer) és az emisszió függvénye az energiafelhasználásnak:

$$
e_{\alpha, \beta}^{r}=e_{\alpha, \beta}^{r}\left(c_{\alpha, \beta}^{e F T}\right) \text { and } e_{\alpha, \beta}^{r}=e_{\alpha, \beta}^{r}\left(c_{\alpha, \beta}^{e F M H}\right)
$$

A fenti tervezési feladat megoldását számos korlátozás befolyásolja. Az első ilyen korlátozás egy kapacitás-alapú korlátozás, mely azt definiálja, hogy nem léphető át a rendelkezésre álló elektromos jármüvek és mikromobilitási eszközök (e-cargo bicikli, e-cargo robogó vagy cargo drón):

$$
\forall \alpha: \max \left(q_{x_{\alpha, 1}}, \sum_{\beta=1}^{2} q_{x_{\alpha, \beta}}, \sum_{\beta=1}^{3} q_{x_{\alpha, \beta}}, \cdots \sum_{\beta=1}^{\beta_{\max }^{\alpha}} q_{x_{\alpha, \beta},}\right) \leq Q_{\alpha}^{\text {Tmax }}
$$

ahol $Q_{\alpha}^{\text {Tmax }}$ az $\alpha$. jármú kapacitása. 
A második korlátozás azt definiálja, hogy minden fel- és leadási feladatot egy előre definiált időablakon belül el kell végezni:

$$
\forall k:(\exists \alpha, \beta) \rightarrow x_{\alpha, \beta+1}=k
$$

A harmadik korlátozás azt definiálja, hogy nem léphető át a rendelkezésre álló rakodási erőforrások kapacitása:

$$
\forall \alpha, \beta: x_{\alpha, \beta}>0 \rightarrow q_{x_{\alpha, \beta}} \leq Q_{\alpha}^{\operatorname{Lmax}}
$$

ahol $Q_{\alpha}^{L m a x}$ az $\alpha$. szállítóeszköz maximális rakodási kapacitása.

A negyedik korlátozás a mobil eszközökre vonatkozó rendelkezésre álló energia mennyiségére vonatkozó korlát (például mikromobilitási eszközök vagy elektromos jármüvek akkumulátor kapacitása):

$$
\forall \alpha: C_{\alpha, \beta_{\max }^{\alpha}}^{e F U E L} \leq C_{\alpha}^{e F U E L \max }
$$

ahol $C_{\alpha, \beta_{\max }^{\alpha}}^{e F U E L}$ az $\alpha$. elektromos jármü részére rendelkezésre álló energia mennyisége a hozzá rendelt utolsó fel- illetve leadási feladat végrehajtását követően és $C_{\alpha}^{e F U E L \max }$ az $\alpha$. jármü részére rendelkezésre álló energia.

Az ötödik korlátozás a rendszer rugalmassága érdekében elöírja az egyes erőforrások egyenletes kihasználtságát, mely azért szükséges, hogy egy valós idejü igény megjelenése esetén minél rugalmasabban, minél több logisztikai erőforrást figyelembe véve lehessen azt a meglévő járatokba illeszteni:

$$
\sum_{\alpha=1}^{\alpha_{\max }}\left|\bar{\eta}-\eta_{\alpha}\right| \rightarrow \min
$$

ahol $\eta_{\alpha}$ az elektromos jármủ kihasználtsága, amely az alábbi módon határozható meg:

$$
\forall \alpha: \eta_{\alpha}=\frac{1}{Q_{\alpha}^{\text {Tmax }}} \cdot \max \left(q_{x_{\alpha, 1}} \sum_{\beta=1}^{2} q_{x_{\alpha, \beta}}, \sum_{\beta=1}^{3} q_{x_{\alpha, \beta},}, \ldots \sum_{\beta=1}^{\beta_{m a x}^{\alpha}} q_{x_{\alpha, \beta},}\right)
$$

és $\bar{\eta}$ az átlagos kihasználtság mértéke, melynek számítása:

$$
\bar{\eta}=\frac{1}{\alpha_{\max }} \cdot \sum_{\alpha=1}^{\alpha_{\max }} \eta_{\alpha}
$$

A hatodik korlátozás azt definiálja, hogy az egyes fel- és leadási feladatok csak az alkalmas logisztikai erőforrások igénybevételével elégíthetők ki:

$$
\forall k: s_{k, \alpha}=0 \rightarrow x_{\alpha, \beta}=0 \text { egyébként } x_{\alpha, \beta} \in(0,1)
$$

ahol $s_{k, \alpha}$ az alkalmassági paraméter; ha $s_{k, \alpha}=1$ akkor az $\alpha$. jármü alkalmas a $k$. fel- vagy leadási feladat elvégzésére, egyébként nem.

\section{Esettanulmány}

Jelen esettanulmány keretében egy többszintes city logisztikai feladat vizsgálata kerül megvalósításra, melybe megjelenik az integrált hulladékgyüjtési folyamat is. Egy logisztikai központ található a kiszolgálandó zóna határán. 30 fel- és leadási feladatot kell végrehajtani elektromos jármüvekkel és mikromobilitási eszközökkel a 25 fel- és leadási ponton. A feladatok koordinátái, a feladatok tömege, rakodási ideje az 1. és 2 . táblázat szerint adott. A 3. táblázat az alkalmassági mátrixot mutatja, mely azt definiálja, 
Bányai, T., Akkad, M. Z., Somody, D.

Intelligens hulladékgyüjtési rendszer a city logisztikában

hogy melyik elektromos jármű vagy mikromobilitási eszköz melyik fel-és leadási feladat végrehajtására alkalmas. Az optimalizálási feladat egyéb bemenő paramétereit a 4. táblázat foglalja össze.

1. táblázat. Fel- és leadási pontok koordinátái (tesztadatok).

\begin{tabular}{|c|c|c|c|c|c|c|c|c|c|c|c|}
\hline \multirow[t]{2}{*}{ ID } & \multicolumn{2}{|c|}{ Koordináta } & \multirow[t]{2}{*}{ ID } & \multicolumn{2}{|c|}{ Koordináta } & \multirow[t]{2}{*}{ ID } & \multicolumn{2}{|c|}{ Koordináta } & \multirow[t]{2}{*}{ ID } & \multicolumn{2}{|c|}{ Koordináta } \\
\hline & $\mathbf{x}$ & $\mathbf{y}$ & & $\mathbf{x}$ & $\mathbf{y}$ & & $\mathbf{x}$ & $\mathbf{y}$ & & $\mathbf{x}$ & $\mathbf{y}$ \\
\hline 1 & 3.745 & 5.905 & 2 & 4.444 & 5.629 & 3 & 5.052 & 5.187 & 4 & 5.532 & 4.608 \\
\hline 5 & 5.852 & 3.928 & 6 & 5.993 & 3.191 & 7 & 5.947 & 2.441 & 8 & 5.715 & 1.725 \\
\hline 9 & 5.313 & 1.091 & 10 & 4.766 & 0.575 & 11 & 4.108 & 0.212 & 12 & 3.381 & 0.024 \\
\hline 13 & 2.628 & 0.023 & 14 & 1.901 & 0.208 & 15 & 1.241 & 0.569 & 16 & 0.692 & 1.083 \\
\hline 17 & 0.288 & 1.716 & 18 & 0.054 & 2.431 & 19 & 0.005 & 3.181 & 20 & 0.144 & 3.919 \\
\hline 21 & 0.462 & 4.601 & 22 & 0.941 & 5.181 & 23 & 1.547 & 5.624 & 24 & 2.245 & 5.903 \\
\hline 25 & 2.991 & 5.999 & REF $^{1}$ & 5.800 & 6.200 & - & - & - & - & - & - \\
\hline
\end{tabular}

${ }^{1} \mathrm{REF}=$ Referenciapont, ahonnan az ellátási lánc indul.

2. táblázat. Fel- és leadási feladatok tömege (teszt adat).

\begin{tabular}{c|ccccccccccccccc}
\hline ID & $\mathbf{1}$ & $\mathbf{2}$ & $\mathbf{3}$ & $\mathbf{4}$ & $\mathbf{5}$ & $\mathbf{6}$ & $\mathbf{7}$ & $\mathbf{8}$ & $\mathbf{9}$ & $\mathbf{1 0}$ & $\mathbf{1 1}$ & $\mathbf{1 2}$ & $\mathbf{1 3}$ & $\mathbf{1 4}$ & $\mathbf{1 5}$ \\
Tömeg & -13 & -23 & -43 & -26 & -65 & -38 & 51 & 31 & 12 & -31 & -12 & 24 & 42 & -23 & 62 \\
Idö & 1.2 & 1.8 & 1.8 & 3.0 & 2.4 & 2.4 & 1.2 & 3.0 & 2.1 & 2.4 & 3.6 & 1.5 & 2.4 & 6.0 & 3.6 \\
ID & $\mathbf{1 6}$ & $\mathbf{1 7}$ & $\mathbf{1 8}$ & $\mathbf{1 9}$ & $\mathbf{2 0}$ & $\mathbf{2 1}$ & $\mathbf{2 2}$ & $\mathbf{2 3}$ & $\mathbf{2 4}$ & $\mathbf{2 5}$ & $\mathbf{2 6}$ & $\mathbf{2 7}$ & $\mathbf{2 8}$ & $\mathbf{2 9}$ & $\mathbf{3 0}$ \\
Tömeg & 27 & 45 & 6 & 56 & -42 & 32 & 34 & 55 & -21 & 20 & 43 & 92 & 34 & 10 & 12 \\
Idö & 2.4 & 3.0 & 2.1 & 1.8 & 3.0 & 2.4 & 1.2 & 12 & 18 & 6.0 & 3.0 & 2.4 & 2.4 & 2.1 & 18 \\
\hline
\end{tabular}

3. táblázat. Logisztikai erőforrások alkalmassági mátrixa.

\begin{tabular}{|c|c|c|c|c|c|c|c|c|c|c|c|c|c|c|c|}
\hline ID & 1 & 2 & 3 & 4 & 5 & 6 & 7 & 8 & 9 & 10 & 11 & 12 & 13 & 14 & 15 \\
\hline $\mathbf{H U}^{1}$ & 1 & 1 & 1 & 1 & 1 & 1 & 0 & 0 & 0 & 0 & 0 & 0 & 0 & 0 & 0 \\
\hline e-T $A^{2}$ & 0 & 0 & 0 & 0 & 0 & 0 & 1 & 0 & 1 & 1 & 1 & 0 & 0 & 1 & 1 \\
\hline e-t $B^{2}$ & 0 & 0 & 0 & 0 & 0 & 0 & 1 & 1 & 0 & 0 & 0 & 0 & 1 & 0 & 1 \\
\hline e-t $C^{2}$ & 0 & 0 & 0 & 0 & 0 & 0 & 0 & 1 & 1 & 1 & 1 & 1 & 1 & 1 & 0 \\
\hline ID & 16 & 17 & 18 & 19 & 20 & 21 & 22 & 23 & 24 & 25 & 26 & 27 & 28 & 29 & 30 \\
\hline $\mathbf{H} \mathbf{U}^{1}$ & 0 & 0 & 0 & 0 & 0 & 0 & 0 & 0 & 0 & 0 & 0 & 0 & 0 & 0 & 0 \\
\hline e-T $A^{2}$ & 1 & 1 & 0 & 0 & 1 & 1 & 0 & 0 & 0 & 1 & 0 & 1 & 1 & 0 & 0 \\
\hline e-t $B^{2}$ & 1 & 0 & 1 & 1 & 0 & 1 & 1 & 1 & 1 & 0 & 0 & 0 & 0 & 1 & 1 \\
\hline e-t $C^{2}$ & 0 & 0 & 1 & 1 & 1 & 0 & 1 & 1 & 1 & 1 & 1 & 0 & 1 & 1 & 1 \\
\hline
\end{tabular}

${ }^{1} \mathrm{HU}=$ hulladékgyüjtő jármü. ${ }^{2} \mathrm{e}-\mathrm{T}=$ elektromos jármü.

4. táblázat. Elektromos jármüvek energiafelhasználása és kapacitása

\begin{tabular}{|c|c|c|c|c|c|c|}
\hline \multirow{2}{*}{ Jármü } & \multicolumn{2}{|c|}{$\begin{array}{l}\text { Energiafogyasztás } \\
\text { Szállítás [kWh] }\end{array}$} & \multicolumn{2}{|c|}{$\begin{array}{c}\text { Energiafogyasztás } \\
\text { Rakodás [kWh] }\end{array}$} & \multicolumn{2}{|c|}{ Kapacitás [ERKE] } \\
\hline & $\min$ & $\max$ & $\min$ & $\max$ & Szállítás & Rakodás \\
\hline HU & 20 & 41 & 14 & 22 & 300 & 80 \\
\hline e-T A & 11 & 18 & 12 & 17 & 350 & 100 \\
\hline e-t B & 12 & 19 & 11 & 16 & 380 & 70 \\
\hline e-t C & 9 & 18 & 10 & 15 & 240 & 60 \\
\hline
\end{tabular}

A fentiekben bemutatott NP-nehéz optimalizálási feladat megoldására az EXCEL Solver evolutív megoldóját használtuk fel az optimális fel- és leadási feladat klaszterek kialakítására és a feladatok, illetve logisztikai erőforrások összerendelésére, valamint az optimális járatok kialakítására. 
Az optimalizálás eredményére példát a 6. és 7. ábra mutat. Az A jármű esetében a teljes járathossz 19.28 $\mathrm{km}$, a teljes járat megtételéhez szükséges idő 1.17 óra rakodással együtt, míg a teljes folyamat energiafelhasználása $4.7 \mathrm{kWh}$.
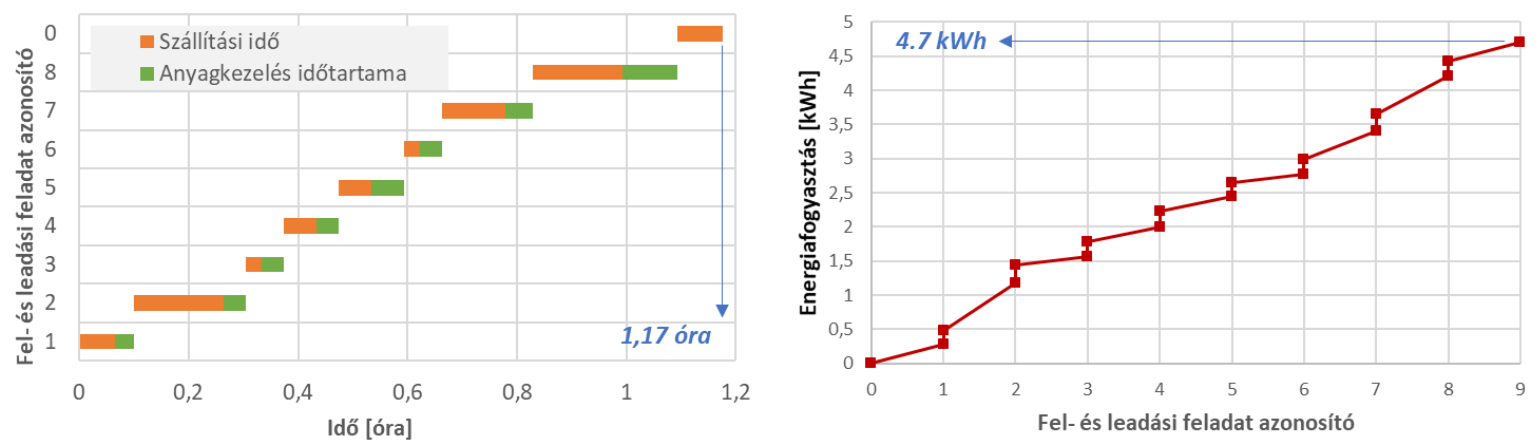

6. ábra. Teljes szállitási idö és energiafelhasználás az A jármü esetében.

Az energiafogyasztáshoz kapcsolódó virtuális emisszió az elektromos energia előállítási forrásának függvényében számítható [20]. Az elektromos energia forrása szén, a csúcsigényeket gázturbina egyenlíti ki. Az A jármü esetében az alábbi emissziós értékek adódnak: $\mathrm{CO}_{2}$ kibocsátás $3810 \mathrm{~g}, \mathrm{NO}_{\mathrm{x}}$ kibocsátás 16.99 g, CO kibocsátás 2.77 g, HC emisszió 1.72 g, PM emisszió 0.13 g és $\mathrm{SO}_{2}$ kibocsátás $0.12 \mathrm{~g}$. A B jármüre ugyanezen adatokat a 7 . ábra mutatja.
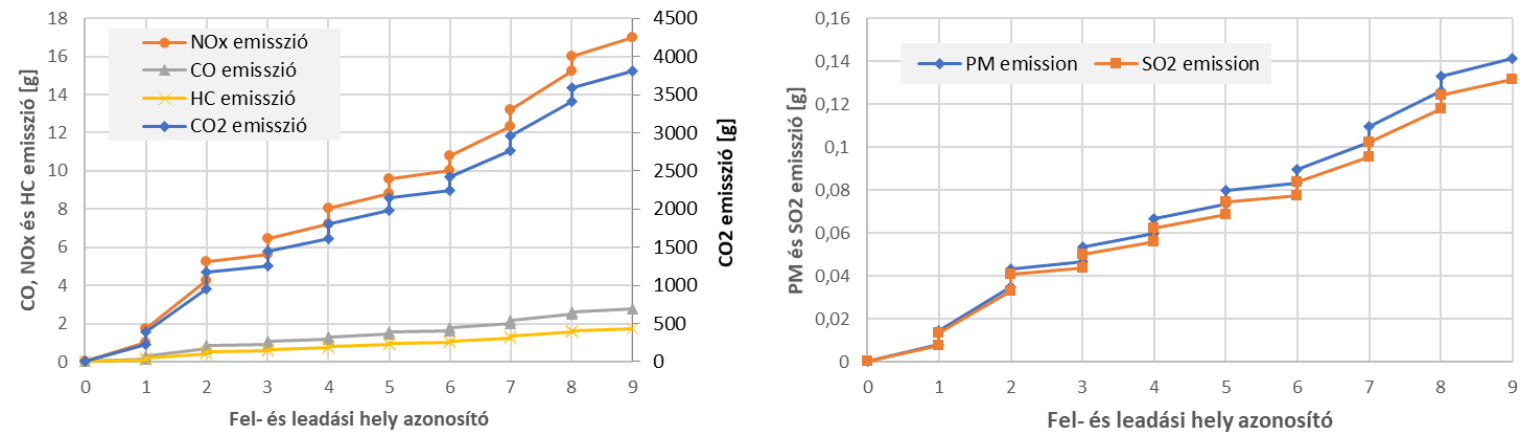

7. ábra. A B jármü emissziós értékei.

A hagyományos city logisztikai megoldások e-jármüvekkel és mikromobilitási eszközökkel való fejlesztése nagy hatással van a city logisztikai folyamatok hatékonyságára, az energiafelhasználásra és az emissziós értékek csökkentésére. Ez azt jelenti, hogy a city logisztikai folyamatok és azon belül a kommunális hulladékgyüjtési folyamatok fejlesztésének jövője a hagyományos megoldások kiber-fizikai rendszerré történő transzformálása Ipar 4.0 technológiák segítségével.

Mint ahogy azt az 5. táblázat is jól összefoglalja, a hagyományos és a kiber-fizikai rendszer között jelentős különbséget lehet felfedezni a károsanyag-kibocsátás szempontjából. Ez egyrészt köszönhető annak, hogy a városi anyagellátási, gyüjtési és elosztási folyamatok integrált kezelésre révén optimális járatok alakíthatóak ki, mely nem csupán azok kihasználtságának fokozásához vezethet, hanem az energiafogyasztás csökkenése révén a károsanyag-kibocsátás csökkenését eredményezi. A másik ok abban keresendö, hogy az elektromos jármüvek és mikromobilitási eszközök alkalmazásával tovább csökkenthető a károsanyag-kibocsátás, miközben a nagy fogyasztású, nagy tömegü és méretü áruk szállítására 
alkalmas járművek tehermentesíthetőek a mikromegbízások (például egy postai levél vagy kisméretű csomag) teljesítése alól.

5. táblázat. Hagyományos és kiber-fizikai rendszer összehasonlitása.

\begin{tabular}{|c|c|c|c|c|c|c|c|c|}
\hline \multirow{2}{*}{$\begin{array}{c}\text { Járat } \\
\text { azonosító }\end{array}$} & \multirow{2}{*}{ Idő } & \multirow{2}{*}{$\mathbf{D I S}^{3}$} & \multicolumn{6}{|c|}{ Emisszió } \\
\hline & & & $\mathrm{CO}_{2}$ & $\mathbf{N O}_{\mathrm{x}}$ & $\mathrm{CO}$ & $\mathrm{HC}$ & PM & $\mathrm{SO}_{2}$ \\
\hline \multicolumn{9}{|l|}{ Hagyományos } \\
\hline Összes & 5.85 & 97.65 & 163653 & 722 & 143.6 & 72.7 & 6.06 & 4.84 \\
\hline Spec $^{1}$ & 0.195 & 3.255 & 5455.1 & 24 & 4.78 & 2.42 & 0.2 & 0.16 \\
\hline Kiber-fizikai & \multicolumn{8}{|c|}{ Víz } \\
\hline Hulladék & 1.02 & 19.04 & 212 & 0.97 & 0.18 & 0.09 & 0.008 & 0.004 \\
\hline Jármü A & 1.17 & 19.28 & 122 & 0.55 & 0.10 & 0.05 & 0.004 & 0.002 \\
\hline Jármü B & 1.17 & 19.22 & 123 & 0.57 & 0.10 & 0.05 & 0.004 & 0.002 \\
\hline Jármü C & 1.16 & 19.1 & 104 & 0.47 & 0.08 & 0.04 & 0.004 & 0.002 \\
\hline Összes & 4.52 & 76.64 & 561 & 2.56 & 0.46 & 0.23 & 0.02 & 0.001 \\
\hline Spec $^{1}$ & 0.15 & 2.55 & 18.7 & 0.085 & 0.015 & 0.007 & $<0.001$ & $<0.001$ \\
\hline Scenario 2 & \multicolumn{8}{|c|}{ Szén és víz } \\
\hline Hulladék & 1.02 & 19.04 & 6622 & 29.53 & 4.81 & 2.98 & 0.22 & 0.20 \\
\hline Jármü A & 1.17 & 19.28 & 3810 & 16.99 & 2.77 & 1.71 & 0.13 & 0.12 \\
\hline Jármü B & 1.17 & 19.22 & 3863 & 17.22 & 2.81 & 1.74 & 0.13 & 0.12 \\
\hline Jármü C & 1.16 & 19.1 & 3242 & 14.46 & 2.35 & 1.46 & 0.11 & 0.10 \\
\hline Total & 4.52 & 76.64 & 17537 & 78.2 & 12.74 & 7.89 & 0.59 & 0.54 \\
\hline Spec $^{1}$ & 0.15 & 2.55 & 584.56 & 2.60 & 0.42 & 0.26 & 0.02 & 0.02 \\
\hline
\end{tabular}

${ }^{1}$ Spec $=$ Egy kiszolgálási feladatra jutó fajlagos kibocsátás értéke.

\section{Eredmények, konklúzió}

A negyedik ipari forradalom mind a termelés, mind a szolgáltatás területén jelentős hatást gyakorol a rendszerek hatékonyságára, hiszen a vertikális és horizontális integráció révén olyan intelligens hálózatok alakíthatóak ki, melyek révén az ellátási lánc egyes szereplői részére kölcsönös haszon érhető el. Ez különösen igaz olyan összetett rendszerek esetében, mint a városi logisztikai rendszerek, ahol a személyés áruforgalom egységét kell úgy megteremteni, hogy a szolgáltatók magas színvonalon tudjanak minőségi szolgáltatást nyújtani alacsony költség és alacsony környezetterhelés mellett. Jelen tanulmány keretében a szerzők felvázolták annak a lehetőségét, hogy hogyan lehetséges a városi logisztikai feladatok integrált kezelése, mely magába foglalja egy belvárosi zóna teljes anyagellátási folyamatát, különös tekintettel a zónában található áruházak áruellátására a kommunális hulladékok gyüjtésére és a postai csomagok kézbesítésére. A bemutatott módszer igazolja, hogy érdemes a hagyományos rendszereket Ipar 4.0 technológiákkal felvértezni és áttranszformálni kiber-fizikai környezetté, hiszen ekkor nem csupán a hatékonyság növelhető, hanem a folyamatok megbízhatósága, pontossága és rendelkezésre állása is fokozható a költségek, átfutási idők energiafelhasználás és emisszió csökkentés mellett. Ebben a fejlődési irányban kiemelt szerepet tölt be az elektromobilitás és a mikromobilitás [21]. Fontos megjegyezni, hogy az elektromos energia előállításának kapcsán egyre nagyobb hangsúlyt kapnak a megújuló energiaforrások, különös tekintettel a napenergiára. Számítások szerint 500 ezer négyzetkilométeres területen elhelyezhető lenne annyi napelem, ami biztosítani tudná bolygón elektromos energia igényét [22].

A bemutatott kutatás tovább bővíthető egyrészt a városi logisztikai folyamatokban tapasztalható bizonytalanságok vizsgálatának irányába sztochasztikus modellek kidolgozásával, másrészt vizsgálható a hagyományos rendszer kiber-fizikai rendszerré történő átalakításának költsége. Érdekes terület lehet a kiegészítő logisztikai müveletek (például rakodási feladatok) vizsgálata [23]. 


\section{Köszönetnyilvánítás}

A cikkben ismertetett kutató munka az EFOP-3.6.1-16-2016-00011 jelü „Fiatalodó és Megújuló Egyetem - Innovatív Tudásváros - a Miskolci Egyetem intelligens szakosodást szolgáló intézményi fejlesztése" projekt részeként - a Széchenyi 2020 keretében - az Európai Unió támogatásával, az Európai Szociális Alap társfinanszírozásával valósul meg.

\section{Irodalom}

[1] Szászi, B., Bányai, Á. A logisztika szerepe a körforgásos gazdaságban. Multidiszciplináris tudományok 2020, 10(1), 178-183. https://doi.org/10.35925/j.multi.2020.2.6

[2] Bányai, T., Tamás, P., Illés, B., Stankevičiūtè, Z., Bányai, Á. Optimization of Munici-pal Waste Collection Routing: Impact of Industry 4.0 Technologies on Environmental Awareness and Sustainability. International Journal of Environmental Research and Public Health 2019, 16(4), 634. https://doi.org/10.3390/ijerph16040634

[3] Gomes, M.I., Barbosa-Povoa, A.P., Novais, A.Q. Modelling a recovery network for WEEE: A case study in Portugal. Waste Management 2011, 31, 1645-1660.

https://doi.org/10.1016/j.wasman.2011.02.023

[4] Mar-Ortiz, J., Adenso-Diaz, B.; Gonzalez-Velarde, J.L. Design of a recovery network for WEEE, collection: The case of Galicia, Spain. Journal of the Operational Research Society 2011, 62, 1471-1484. https://doi.org/10.1057/jors.2010.114

[5] Demirel, E., Demirel, N., Gokcen, H. A mixed integer linear programming model to optimize reverse logistics activities of end-of-life vehicles in Turkey. Journal of Clean Production 2016, 112, 2101-2113. https://doi.org/10.1016/j.jclepro.2014.10.079

[6] Illés, B., Varga, K.A., Czap, L. Logistics and Digitization. Lecture Notes in Mechanical Engineering 2018, 220-225. https://doi.org/10.1007/978-3-319-75677-6_18

[7] Felhő, Cs., Kundrák, J. CAD-based modelling of surface roughness in face milling. World Academy of Science Engineering and Technology 2014, 8(5), 71-75.

[8] Lu, Y. Industry 4.0: A survey on technologies, applications and open research issues. Journal of Industrial Information Integration 2017, 6, 1-10. https://doi.org/10.1016/j.jii.2017.04.005

[9] Reck, D.J., Haitao, H., Guidon, S., Axhausen, K.W. Explaining shared micromobility usage, competition and mode choice by modelling empirical data from Zurich, Switzerland. Transportation Research Part C: Emerging Technologies 2021, 124, 102947. https://doi.org/10.1016/j.trc.2020.102947

[10] Oeschger, G., Carroll, P., Caulfield, B. Micromobility and public transport integration: The current state of knowledge. Transportation Research Part D: Transport and Environment 2020, 89, 102628. https://doi.org/10.1016/j.trd.2020.102628

[11] Fitt, H., Curl, A. The early days of shared micromobility: A social practices approach. Journal of Transport Geography 2020, 86, 102779. https://doi.org/10.1016/j.jtrangeo.2020.102779

[12] Lazarus, J., Pourquier, J. C., Feng, F., Hammel, H., Shaheen, S. Micromobility evolution and expansion: Understanding how docked and dockless bikesharing models complement and compete - A case study of San Francisco. Journal of Transport Geography 2020, 84, 102620. https://doi.org/10.1016/j.jtrangeo.2019.102620

[13] Segway Ninebot One S2. Online elérhető: https://www.muziker.hu/segway-ninebot-one-s2 Letöltve: 2021.01.31. 
[14] OneWheel - We are in the business of making the future rad. Online elérhetö: https://onewheel.com/pages/about-us Letöltve: 2021.01.22.

[15] Pedelec és elektromos kerékpár okosoldal - így válaszd ki a megfelelő modell. Online elérhető: https://www.bicajozz.hu/e-bike-pedelec-kerekpar-okosoldal/ Letöltve: 2021.01.23.

[16] Strahl, J. Apró, de bámulatos! Online elérhető: https://www.volkswagen.hu/e-mobilitas-es-idhub/id-hub/id-magazin/mikromobilitas Letöltve: 2021.01.12.

[17] Microletta - Drei räder sind besser als zwei. Online elérhető: https://microlino-car.com/de/microletta Letöltve: 2021.01.26.

[18] Microlino - Der ideale Mix zwischen Motorrad und Auto. Online elérhető: https://microlinocar.com/de/microlino Letöltve: 2021.01.30.

[19] Akkad, M.Z., Bányai, T. Cyber-physical waste collection system: a logistics approach. In: Szita Tóthné, Klára; Jármai, Károly; Voith, Katalin (szerk.) Solutions for Sustainable Development: Proceedings of the 1st International Conference on Engineering Solutions for Sustainable Development, (ICESSD 2019) London, Egyesült Királyság / Anglia: CRC Press (2019) 394 p. pp. 160168. https://doi.org/10.1201/9780367824037-21

[20] World Nuclear Association. Comparison of lifecycle greenhouse gas emissions of various electricity generation sources; World Nuclear Association: London. UK. 2011; pp. 1-12.

[21] Orosz, T., Veres, P., Bányai, Á. Elektromobilitás az áruszállításban. Multidiszciplináris Tudományok: A Miskolci Egyetem Közleménye 2019, 9(1), 88-95. https://doi.org/10.35925/j.multi.2019.1.12

[22] Harrington, R. Here's how much of the world would need to be covered in solar panels to po-wer Earth. Online elérhetö: https://www.businessinsider.com/map-shows-solar-panels-to-power-theearth-2015-9?r=UK Letöltve: 2021.02.19.

[23] Vida, L., Illés, B., Bányai, Á. Multimodális egységrakomány rakodási problémáinak megoldá-sa. Multidiszciplináris tudományok 2020, 10(2), 37-42.

https://doi.org/10.35925/j.multi.2020.1.21 